\title{
Certification of Work Competencies of Port Operational Workers PT. Pelindo III and PT. Pelindo IV in The Mutual Recognition Arrangement
}

\author{
Trisnowati Rahayu ${ }^{1}$, Hasiah ${ }^{2}$, Jumriani ${ }^{2}$ \\ ${ }^{1}$ Politeknik Pelayaran Surabaya, ${ }^{2}$ Politeknik Ilmu Pelayaran Makassar \\ e-mail:trisjafar@gmail.com
}

\begin{abstract}
The analyze ability and skills certification of port and TKBM officers in carrying out goods loading and unloading activities at the port, as is known for the many work accidents that often occur at port and TKBM officers due to lack of skills in using tools the loading and unloading of goods and appropriate work safety equipment in terms of work competency aspects in accordance with SKKNI standards. the type of research to be used is the type of qualitative research. The research location is in PT. Pelindo III Surabaya Branch and the PT. Pelindo IV. The results of the study and discussion it can be concluded that the port operational officer and the port loading and unloading workers in the PT. Pelindo III and PT. Pelindo IV has largely been not certified by the National Professional Certification Agency-Jakarta. Port operational officers and port loading and unloading workers are still equipped with certificates issued by the Indonesian Ministry of Manpower up to each of the Manpower Offices in the PT. Pelindo III and PT. Pelindo IV.
\end{abstract}

Keywords: Certification, work competency, port operational officer.

\section{Introduction}

In the implementation of national development, manpower has a very important role and position as an agent and development goal. That in accordance with the role and position of the workforce, employment development is needed to improve the quality of the workforce and its participation in development and to improve the protection of workers and their families in accordance with human dignity and dignity. Whereas Law no. 17/2008 on Shipping mandates that Indonesia must develop an "efficient, competitive and responsive port system". Education must be the foundation of this reform. Another challenge of the Indonesian workforce or human resources, namely the entry into force of the ASEAN Economic Community On December 31, 2015 the ASEAN Economic Community (AEC) was declared. Related to labor issues, we focus on the fifth free flow, namely the free flow of skilled labor (free flow of skilled labor). In accordance with the WTO provisions on trade in services, to guarantee the objectivity of recognition of labor expertise, the mobility of labor (movement of natural persons) between countries must be carried out through the mechanism of mutual

Recognition of expertise equality (Mutual Recognition Arrangement / MRA). What is Indonesia's readiness to face the AEC? To answer that question, we first look at our current employment conditions. Talking about the quality and competitiveness of the workforce compared to other ASEAN countries, the conditions were less encouraging. 
In order to improve the skills and competencies of port officers and Unloading Workers (TKBM) in all ports in Indonesia, the UPT under the Ministry of Transportation and institutions related to ports conduct education and training for port officers and TKBM at ports. The importance of the competence of port operational officers and TKBM at the Port in order to improve the skills and role of port workers in the free competition of the Asean economic community (MEA) at this time. The reason is that port officials and port workers are now demanded to be more professional and productive in encouraging loading and unloading productivity and the smooth flow of goods to and from the port. the theme to be raised is to thoroughly analyze the certification of the ability and skills of port and TKBM officers in carrying out goods loading and unloading activities at the port, as is known to the many work accidents that often occur at port and TKBM officers due to lack of skills in using safety equipment and work skills that are the skills and abilities of port officers and TKBM (in terms of work competency aspects according to SKKNI standards). Whereas in the location of the selection in this study, more directed at operational officers and TKBM who are in the environment of the Port of Indonesia III (representing the Western region) and the Port of Indonesia IV (representing the Eastern region).

\section{Research Methods \\ Types of Research}

Based on the focus of research that has been described in the formulation of the problem, the type of research to be used is the type of qualitative research. Whereas this qualitative research procedure will produce descriptive data in the form of written or oral words from people and observable behavior (Bogdan and Taylordalam Moleong, 2008). With this type of qualitative engineering research aims to find out more in depth BNSP unloading activities. The approach used in this research is a case study. loading goods carried out by officers and TKBM who obtain certificates from a research approach designed using case studies aimed at describing a specific setting, object or event in detail and in depth.

\section{Data Collection and Data Validation Techniques}

Data collection techniques adapted to the purpose of the study. Data collection techniques in this study, including: 1. Interview Interview Guidelines are guidelines that are prepared by including the main questions raised by informants. This guideline is prepared based on the focus of the problem under study. The forms of questions asked are unstructured questions. Given the limitations of researchers in terms of recording and remembering data and information, and so that the results of interviews can be recorded properly, then in conducting interviews the researcher uses tools such as; tape recorder and digital camera. In addition, the researcher also tries to make an effort by creating a close relationship, so that respondents feel calm and answer questions according to the actual conditions. Real conditions can provide true information so that data / information can be obtained accurately \& accurately in accordance with the focus of research. 2 . Document Study The required documents are various written and unwritten documents that show or describe important data and information relating to the carrying out of goods at this port, such as; Laws, Government Regulations, Presidential Decrees, Regional Regulations. 
Observation The participatory observation activities undertaken by the researcher are participant observation is not full. Participant observation is not fully intended that the researcher is not directly involved in the activities of the research subject but only sees, listens and interviews. Data obtained through participant observation is recorded in a book in detail to field notes. In addition to using field notes, documentation tools such as digital photo cameras and recording devices are used to capture important events that occur in the field. From these observations it is hoped that meaningful findings can be obtained to answer the problem of the research focus.

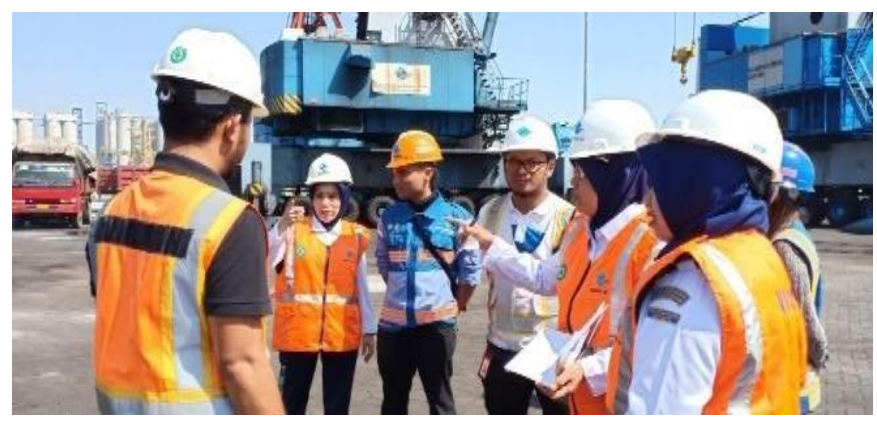

Figure 1.

\section{Data Analysis Technique}

This study uses a qualitative approach, so as to maintain the objectivity of the research results, the data obtained will then be reconstructed based on the context and reality described by the actors or actors involved. The collected data is then analyzed using qualitative analysis techniques with the following steps; gathering and collecting data from various sources in the form of documents, interviews, observations during the research process. for the next process in the meaning of the data obtained to subsequently be used as a result of research.

\section{Research Results and Discussion.}

\subsection{Research Results}

Supervisor Certification at the Port Operational Terminal at PT. Pelindo III and IV, Certification In accordance with the research topic, which wants to find out work competencies in accordance with SKKNI for field officers including; supervisors, foremen, equipment operators, competency tests have never been carried out as stated by BNSP that each occupancy position must have a competency certificate. According to the supervisors' recognition, they are equipped with training and education to support the implementation of their duties as supervisors, foremen, equipment operators, they are provided with training and education to support the implementation of duties as Foreman. Such as B / M Basic Management, B / M Basic Training and container movement. As for occupancy positions of the Operation Equipment Unloading Certification Scheme such as operating forklifts, rubber tire gantries, container cranes, each officer has an operator license (SIO) issued by the employment agency in each region, as shown in the figure below. 

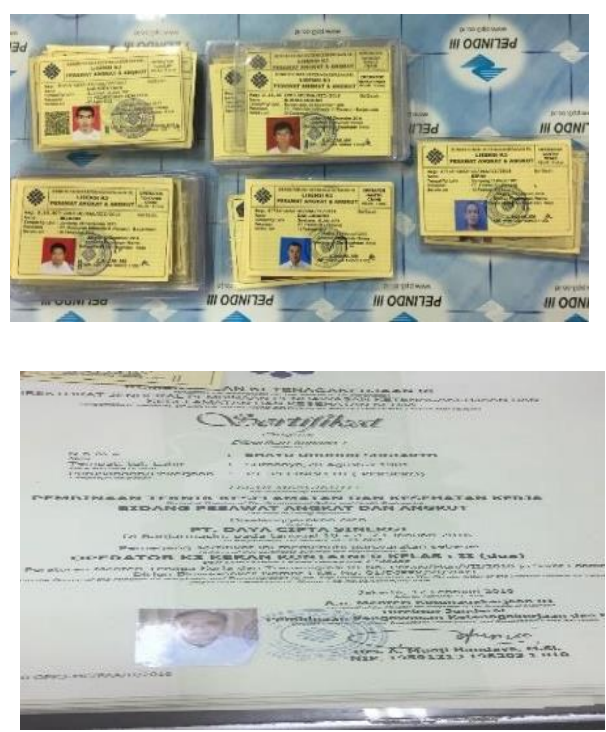

Figure 2

So it can be concluded that all certificates obtained by the port operational officers and the port loading and unloading workers from the Indonesian Ministry of Manpower. This is contrary to the function of the government which assigns the BNSP to test the competency of workers.

\subsection{Discussion}

From the research results obtained through observation and interview activities both at PT. Pelindo III and PT. Pelindo IV is as follows: 1. Operational officers at the port and TKBM in carrying out activities have been provided with various training and training that support the implementation of their duties. In general, education and training carried out by agencies from Pelindo, educational and training institutions in the field of shipping and employment services in the local area. If the training is held to test the skills and abilities of an operational officer at a port or TKBM then it is carried out by the agency that organizes training, for example if a container crane operator receives training to operate container cranes from the East Java propensity employment office, then the operator issuing a permit (SIO) from on behalf of the Indonesian Ministry of Labor. Like the example below. 2. The results of the study indicate that most of the port operational officers and loading and unloading workers in the Pelindo III and Pelindo IV areas have not been certified by the National Professional Certification Agency (BNSP). In line with the opinion of the Chairperson of the Indonesian Professional Loading and Unloading Certification Institute (LSP-BMI) Sodik Harjono who said: "That TKBM certification at the port is mandated in applicable legislation including through the Minister of Transportation's Regulation Number. 60 of 2014 concerning the Implementation and Execution of Loading and Unloading Goods from and to ships. Goods loading and unloading activities at the port must be carried out using loading and unloading equipment by TKBM that meets the standard, operation-worthy equipment to ensure the safety of shipping. Furthermore, the Chairperson of the Indonesian loading and unloading LSP (LSP-BMI) revealed that until now the TKBM who have obtained certification do not exceed $5 \%$ of the total number of port workers who work in Indonesian ports. 
As is known that the ASEAN Economic Community (AEC) has been implemented. MEA is the realization of a free market carried out by Southeast Asian countries including, Malaysia, Singapore, Thailand, Brunei Darussalam, Myanmar, Vietnam, Laos, Cambodia and Indonesia. The purpose of the 2015 ASEAN Economic Community is to improve economic stability and growth in the ASEAN region, so that the establishment of the 2015 ASEAN economic region is expected to be able to overcome problems, especially in the economic field between ASEAN countries, and for Indonesia, it is hoped that there will not be a crisis again. in this country.

With the implementation of the MEA, there will be a free market in the areas of capital, goods and services, as well as labor which will have an impact on the free flow of goods for ASEAN countries, the impact of free flow of services, the impact of free flow of investment, the impact of labor flows, and the impact of free capital flows. Thus, the countries that enter the MEA will compete to improve the quality of their respective economies including Indonesia. Indonesia must really take advantage of this free market so that the Indonesian economy can grow rapidly and be able to enjoy the benefits of the MEA and later the welfare of the Indonesian people will be created. If not, then Indonesia will be unable to compete with other countries and the people will be the victims.

From here, it can be found for the Shipping Polytechnic Institution, especially the Sea Transportation and Harbor Study Management program to take steps in synergy with agencies related to the port to conduct a training program followed by the implementation of a competency test (LSP-P1 PIP Makassar) for operational officers port and TKBM.

Actually not only the government must be ready to face this MEA but the Indonesian people must also participate in the success of this free market. Because the existence of this MEA can not be separated from all walks of life. With the 2015 MEA it should be our driving force and encouragement that this ASEAN program can stabilize Indonesia's economic growth in the future which will prosper the Indonesian people. In addition, we must eliminate doubts and worries by staying focused, committed, and working hard from all parties to jointly succeed in the utilization of the 2015 Asean Economic Community.

Furthermore, in the MEA 2015 era, labor market mobility in the ASEAN region will be more open and free. This will have an impact on opening up opportunities as well as fierce work competition among ASEAN countries. The current workforce needs orientation has shifted from an academic degree to work competency.

\section{Conclusion}

From the results of the study and discussion it can be concluded that the port operational officer and the port loading and unloading workers in the PT. Pelindo III and PT. Pelindo IV has largely been not certified by the National Professional Certification Agency (BNSP) -Jakarta. Port operational officers and port loading and unloading workers are still equipped with certificates issued by the Indonesian Ministry of Labor up. each Manpower office in the working area of PT. Pelindo III and PT. Pelindo IV.

\section{References}

[1] Fogg, Luthans. 2004. Organizational Behaviour, NY: MC Graw-Hill Book. http://industri.bisnis.com/read/20161111/98/601504/bongkar-muat-pbm-bupperlu-dorong-sertifikasi-buruh-pelabuhan) di akses tgl 23 Juli 2018

[2] Mardalis. 2008. Metode Penelitian Suatu Pendekatan Proposal, Bumi Aksara, 
Jakarta.

[3] Menteri Perhubungan. 2002. Keputusan Menhub No. KM 25 tahun 2002 tentang pedoman dasar perhitungan tariff pelayanan jasa bongkar muat barang dari dan ke kapal di pelabuhan.Jakarta : Kementrian Perhubungan.

[4] Menteri Tenaga Kerja dan Transmigrasi, 2013, Keputusan Menakertrans nomor 141 Tahun 2013 pada Tanggal 17 April 2013 Tentang SKKNI.Jakarta : Kenakertrans.

[5] Nazir, Moh. 1998. Metode Penelitian, Ghalia Indonesia, Jakarta.

[6] Palan. 2007. Competency management: Teknis Mengimplementasikan Manajemen Sumber Daya Manusia Berbasis Kompetensi Untuk Meningkatkan Daya Saing Organisasi PPM, Salemba Empat, Jakarta.

[7] PM 60 tahun 2014 tentang Penyelenggaraan dan Pengusahaan Bongkar Muat Barang dari dan ke Kapal

[8] PM 152 tahun 2016 Penyelenggaraan Dan Pengusahaan Bongkar Muat Barang Dari Dan Ke Kapal.

[9] Powell, J., 1997. Improving Child Health, Geneva, World Health Organization.

[10] Robbins P. Stephen. 2006. Organization Behaviour, Concepts, Controversies, Application.

[11] Seventh Edition,: Prentice Hall, Inc., New York.

[12] Roe. Robert A. 2001. Trust Implications for Performance and Efectiveness, European Journal. Spencer, Lyle M and Spencer, Signe M. 1993. Competence at Work, Models for Superior

[13] Performance, John Wiley \& Sons, Inc. Toronto, Canada.

[14] Suparno, Paul.,2005. Miskonsepsi dan Perubahan Konsep dalam Pendidikan Fisika, PT. Gramedia Widia Sarana, Yogyakarta.

[15] Undang Undang Nomor 17 Tahun 2008 tentang Pelayaran.

[16] Wibowo. 2007. Manajemen Kinerja, PT. Raja Grafindo Persada, Jakarta.

[17] Warsito, Hermawan. 1992. Pengantar Metodologi Penelitian, Gramedia, Pustaka Utama, Jakarta. 